\title{
Potential use of geothermal energy sources for the production of lithium-ion batteries
}

\author{
Pai-chun Tao, Hlynur Stefansson, William Harvey, Gudrun Saevarsdottir \\ ${ }^{1}$ Reykjavik University, Reykjavik, Iceland \\ * Corresponding author. Tel: +354 599-6345, Fax: +354 599-6201, E-mail: gudrunsa@ru.is
}

\begin{abstract}
The lithium-ion battery is one of the most promising technologies for energy storage in many recent and emerging applications. However, the cost of lithium-ion batteries limits their penetration in the public market. Energy input is a significant cost driver for lithium batteries due to both the electrical and thermal energy required in the production process. The drying process requires $45 \sim 57 \%$ of the energy consumption of the production process according to a model presented in this paper. The model is used as a base for quantifying the energy and temperatures at each step, as replacing electric energy with thermal energy is considered. In Iceland, it is possible to use geothermal steam as a thermal resource in the drying process. The most feasible type of dryer and heating method for lithium batteries would be a tray dryer (batch) using a conduction heating method under vacuum operation. Replacing conventional heat sources with heat from geothermal steam in Iceland, we can lower the energy cost to $0.008 \mathrm{USD} / \mathrm{Ah}$ from $0.13 \mathrm{USD} / \mathrm{Ah}$ based on average European energy prices. The energy expenditure after 15 years operation could be close to $2 \%$ of total expenditure using this renewable resource, down from $12 \sim 15 \%$ in other European countries. According to our profitability model, the internal rate of return of this project will increase from $11 \%$ to $23 \%$ by replacing the energy source. The impact on carbon emissions amounts to 393.4-215.1g/Ah lower releases of $\mathrm{CO}_{2}$ per year, which is only $2-5 \%$ of carbon emissions related to battery production using traditional energy sources.
\end{abstract}

Keywords: Lithium ion battery, Geothermal energy, Energy cost, Carbon emission

\section{Introduction}

The exponential growth in the use of portable electronic devices and electric vehicles has created enormous interest in inexpensive, compact, light-weight batteries offering high energy density. Clearly, the lithium-ion battery is one of the most appealing technologies to satisfy this need. It is estimated that the global market for lithium-ion batteries could grow from $\$ 877$ million in 2010 to $\$ 8$ billion by 2015[1]. However, cost limits their penetration in the global market. Energy is a significant cost driver for lithium batteries as both electrical and thermal energy is required in the raw materials processing and battery manufacturing and assembly. As energy use is significant in the process, the sustainability of the energy source influences the overall carbon footprint for the battery production. Iceland offers a number of potential avenues for cost and carbon emissions reductions in the manufacturing process, due to readily available medium grade thermal energy from geothermal or industrial sources, access to inexpensive renewable electricity, and a skilled workforce. The purpose of this paper is to quantify the economic advantages and carbon emission reductions to be gained by locating a lithium iron phosphate $\left(\mathrm{LiFePO}_{4}\right)$ factory in Iceland close to geothermal heat sources, versus sites in other locations where fossil sources of energy must be used. Furthermore, we will also present the sensitivity of profitability to energy cost.

\section{Methodology}

The presented work consists of three main tasks: 1) Collection of relevant data and information. 2) Estimation of energy consumption and temperature levels at various steps in the production process and 3) Assessment of profitability and impact on carbon emissions. Firstly, the literature review, including interview data, provides us with information to draw a complete production process map of the lithium iron phosphate battery manufacturing process. Unfortunately, detailed energy consumption data from each step in the lithium 
battery production is not readily available from factories due to confidentiality reasons in this competitive market. Consequently, we build a theoretical energy consumption model for the drying process based on the thermal

properties and moisture content of materials in the batteries, basic physical formulas, and industrial experience. There are some uncertainties in this model, as energy efficiency, and heat loss, are based on educated assumptions. The results from the model are therefore not data from an actual factory, but should be informative none the less. In reality, it could be lower or higher depending on de sign of industrial equipment components. For the profitability assessment, common standards of estimating the profit of an investment, for example, net present value (NPV) and the internal rate of return (IRR) are applied. Consequently, we build a comprehensive profitability assessment model for building a Table 2-1 Main assumptions of profitability model

\begin{tabular}{ll}
\hline Items & Value \\
\hline Interest rate of loan & $12 \%$ \\
\hline Sale price & $\begin{array}{l}1.44 \quad \text { (USD/Ah) with } 3 \% \\
\text { annual decreasing trend }\end{array}$ \\
\hline Raw material price & $\begin{array}{l}0.69 \quad \text { (USD/Ah) with 2.75\% } \\
\text { annual decreasing trend }\end{array}$ \\
\hline Initial investment & 9612 million ISK \\
\hline Discount Rate & $15 \%$ \\
\hline Capital structure & $70 \%$ loan, 30\% equity \\
\hline Exchange rate & $\begin{array}{l}156 \text { (ISK/Euro) } \\
112 \text { (ISK/USD) }\end{array}$ \\
\hline Salary for workers & $\begin{array}{l}\text { Iceland: 238,000 (ISK/Month) } \\
\text { Germany: 1944 (€/Month) }\end{array}$ \\
\hline
\end{tabular}
new lithium iron phosphate battery factory in Iceland. Most cost data are obtained directly from suppliers or publicly available information. The main assumptions are listed in Table 2.1. In the model, we make several financial assumptions, such as interest rate, capital structure and discount rate of based on current conditions in Iceland. The profitability calculation and Monte Carlo analysis are performed by Microsoft Excel plug in with@Risk5.7.

\section{Energy consumption of Lithium Iron Phosphate battery production process}

\subsection{Energy consumption of entire process}

Energy consumption in lithium iron battery production is not openly available information from this emerging industry. Lifecycle analysis of lithium iron battery by Mats Zackrisson and Lars Avellán in 2010 claims that the total energy consumption corresponds to $11.7 \mathrm{kWh}$ electricity and $8.8 \mathrm{kWh}$ of thermal energy from natural gas per $\mathrm{kg}$ lithium-ion battery [2]. This corresponds to an energy consumption for 1Ah battery of approximately $0.68 \mathrm{KWh}$, assuming that one $\mathrm{kg}$ lithium-ion provides $30 \mathrm{Ah}$ capacity of battery. In addition, energy consumption data were obtained from Matti Nuutinen, who reported data from a Chinese lithium iron phosphate battery factory and for European Batteries Oy[3].

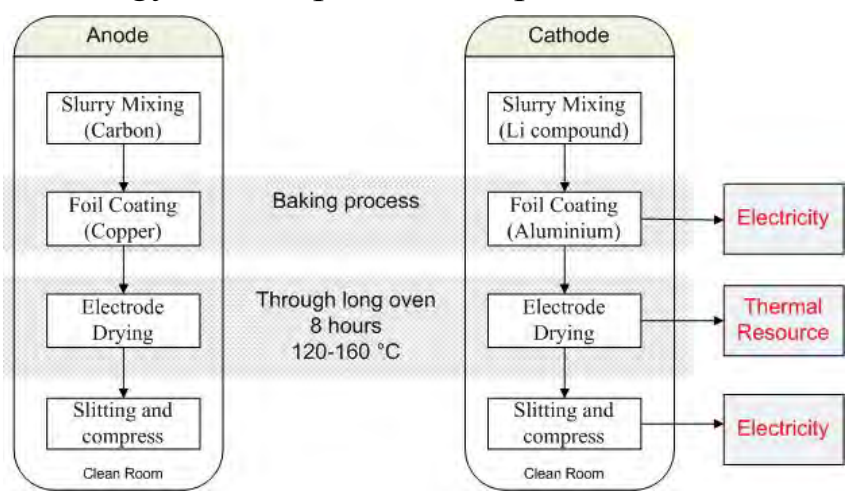
In this report, Nuutinen shows that Figure 3-1 Production process map of Part 1 $5000 \mathrm{kw}$ electric power is required to produce 80MAh battery per year. This equates to energy consumption for producing $1 \mathrm{Ah}$ battery is approximately $0.54 \mathrm{KWh}$. Based on these sources the energy consumption could range from 0.54 to $0.68 \mathrm{KWh} / \mathrm{Ah}$ according to our investigation. 


\subsection{Production process map}

In general, our analysis of the lithium iron battery production process starts with the various raw materials and components from suppliers. The overall process can be divided into two parts: preparation of electrodes and cells assembly. Fig 3-1 shows the main steps in first part of the production process. In first part, the first step is to mix anode and cathode powders with solvent and binder, coat them on the respective foils, and dry them in the vacuum oven at around $120^{\circ} \mathrm{C}$ for 8 hours. Traditionally the heat applied at each of the drying steps is obtained by electric heating. However, since the temperature needed in the vacuum oven is relatively low, we might be able to replace electric heating with heat exchangers using geothermal steam as a thermal source. After this drying step the electrode disks would be cut into suitable sizes and compressed thinner by automatic machines. At this stage, the individual electrode is ready for assembly.

Fig 3-2 shows the second part, which is to assemble the various components, such as the separators, internal circuits, anodes and cathode altogether. In this step, the electrodes can be stacked and clamped first and put into a metal packing case. Afterwards, the battery cells are placed in the core drying machines. The purpose of this step is to remove the remaining moisture from electrodes completely. This is the most energy intensive step of the whole



Figure 3-2 Production process map of Part 2 process. In principle it w ould seem feasible to accelerate this drying step by increasing the temperature in the oven. However, the melting point of the binder (PVDF) is around $170^{\circ} \mathrm{C}$, so the temperature in the vacuum oven must be kept below $170^{\circ} \mathrm{C}$. As an alternative the process is accelerated by lowering the pressure in the oven in order to efficiently remove the vapor formed. Thereby the boiling point of water and solvent is decreased in order to shorten the drying process. In the end, the moisture content rate in the electrodes is reduced to 500ppm [4]. After the core drying process, the electrolyte is injected into cell and it is sealed completely. Since the electrodes are very sensitive to moisture, those processes are usually operated in a room, where the humidity is kept at an acceptable level. In principle, the battery pack is ready for use at this stage. However, most producers test their products several times in order to ensure its performance and collect data before shipping the product to consumers.

\subsection{Energy consumption of the drying process}

Through production analysis, the approximate energy consumption figure has been already addressed in the previous text. But, we need to know the energy consumption of the drying process, if we want to consider alternative energy resources for the drying process. Consequently, we build a theoretical calculation model. It is not perfect, but a reasonable approach to figure out the approximate energy consumption of the drying process. The first step of building an energy consumption model of drying is to collect the weight percentage and thermal properties of component materials. Table 3-1, shows the physical thermal properties of each material in the lithium iron battery. 
Table 3-1 Physical properties of component material

Information of $1 \mathrm{~kg}$ lithium iron battery component material

\begin{tabular}{|c|c|c|c|}
\hline $\begin{array}{c}\text { Cathode } \\
\text { Composition }\end{array}$ & Weight (g) & Heat capacity & Others \\
\hline $\mathrm{LiFePO}_{4}$ & $422 \mathrm{~g} \mathrm{[2]}$ & $\mathrm{C}_{\mathrm{v}}: 0.9 \mathrm{~J} / \mathrm{g}-\mathrm{K}[2]$ & Melting point: $223^{\circ} \mathrm{C}$ \\
\hline Al foil & $19 \mathrm{~g}[2]$ & $\mathrm{C}_{\mathrm{P}}\left(25^{\circ} \mathrm{C}\right) 0.89 \mathrm{~J} / \mathrm{g}-\mathrm{K}$ & Melting point: $660.3^{\circ} \mathrm{C}$ \\
\hline Carbon black & $27 \mathrm{~g}[2]$ & $\mathrm{C}_{\mathrm{P}}\left(25^{\circ} \mathrm{C}\right): 0.71 \mathrm{~J} / \mathrm{g}-\mathrm{K}$ & Melting point: $3500^{\circ} \mathrm{C}$ \\
\hline Binder (PVDF) & $28 \mathrm{~g}$ [2] & $\mathrm{C}_{\mathrm{v}}: 1.9 \mathrm{~J} / \mathrm{g}-\mathrm{K}[5]$ & Melting point: $170^{\circ} \mathrm{C}$ \\
\hline NMP solvent & $\begin{array}{l}\text { Initial: } 244.2 \mathrm{~g} \\
\text { Outlet: } 10 \mathrm{~g}[6]\end{array}$ & $\mathrm{C}_{\mathrm{v}}: 1.76 \mathrm{~J} / \mathrm{g}-\mathrm{K}[7]$ & $\begin{array}{l}\text { Boiling point: } 202^{\circ} \mathrm{C} \\
\text { Heat of vaporization, } \\
20^{\circ} \mathrm{C}: 550.5 \mathrm{KJ} / \mathrm{g}[6]\end{array}$ \\
\hline \multicolumn{4}{|l|}{$\begin{array}{c}\text { Anode } \\
\text { Composition }\end{array}$} \\
\hline Graphite & $169 \mathrm{~g} \mathrm{[2]}$ & $\mathrm{C}_{\mathrm{P}}\left(25^{\circ} \mathrm{C}\right): 0.71 \mathrm{~J} / \mathrm{g}-\mathrm{K}$ & Melting point: $3500^{\circ} \mathrm{C}$ \\
\hline $\mathrm{Cu}$ foil & $46 \mathrm{~g}[2]$ & $\mathrm{C}_{\mathrm{p}}\left(25^{\circ} \mathrm{C}\right): 0.385 \mathrm{~J} / \mathrm{g}-\mathrm{K}$ & Melting point: $1084.6^{\circ} \mathrm{C}$ \\
\hline NMP solvent & $\begin{array}{l}\text { Initial: } 116.2 \mathrm{~g} \\
\text { Outlet: } 4.8 \mathrm{~g}[6]\end{array}$ & $\mathrm{C}_{\mathrm{v}}: 1.76 \mathrm{~J} / \mathrm{g}-\mathrm{K}[7]$ & $\begin{array}{l}\text { Boiling point: } 202^{\circ} \mathrm{C} \\
\text { Heat of vaporization, } \\
20^{\circ} \mathrm{C}: 550.5 \mathrm{KJ} / \mathrm{g}[6]\end{array}$ \\
\hline Total moisture & $\begin{array}{c}\text { Initial: } 4.5 \mathrm{~g} \\
\text { Outlet: } 0.5 \mathrm{~g}[4]\end{array}$ & $\begin{array}{c}\mathrm{C}_{\mathrm{v}}\left(25^{\circ} \mathrm{C}\right): 4.18 \mathrm{~J} / \mathrm{g}-\mathrm{K} \\
\mathrm{C}_{\mathrm{v}}\left(100^{\circ} \mathrm{C}, \text { steam }\right): \\
2.08\end{array}$ & $\begin{array}{c}\text { Evaporation energy: } 2270 \\
\mathrm{KJ} / \mathrm{g})\end{array}$ \\
\hline
\end{tabular}

The model predicts how much thermal energy we need in order to remove the moisture and NMP from the electrodes. It is accompanied with the increasing temperature of other materials and some heat lost to environmental. The thermal energy consumption of the drying process calculation could be divided into two parts. (1) The energy for increasing the temperature of all component materials. (2) The energy for evaporating the moisture and NMP away from the feedstock. Through the thermal properties and some basic physical formulas, we obtain theoretical results for both parts respectively. And then, we take the empirical energy efficiency of the vacuum dryer into account to get more realistic data. The energy required for heating the materials to the dryer temperature would is $128.62 \mathrm{~kJ} / \mathrm{kg}$. The second part is the energy consumption of evaporation. It dominates the energy consumption of drying process. The overall energy consumption of evaporation is $198197.8 \mathrm{~kJ} / \mathrm{kg}$. The key factors in this calculation are the initial weight and outlet weight of moisture because the heat of evaporation of water and solvent dominates as compared to the sensible heat. However, the energy efficiency is not $100 \%$. Based on the literature we assume that the energy efficiency of the vacuum dryer is 0.6 according to the Handbook of Industrial Drying [8]. In this case, the practical energy consumption would be $0.186 / 0.6=0.26 \mathrm{KWh} / \mathrm{Ah}$. As a consequence the energy required is approximately $0.31 \mathrm{KWh}$ thermal to dry $1 \mathrm{Ah}$ of lithium iron phosphate battery. This number does not include the electricity for vacuum machines and drying rooms, which are also part of the drying system. It only focuses on the thermal energy that can be replaced by geothermal steam. According to the energy consumption data in previous research, the whole energy consumption of producing 1Ah lithium battery would raised from $0.54 \sim 0.68 \mathrm{KWh}$. Based on this information $45 \sim 57 \%$ of the energy consumed by the process can be replaced by an alternative thermal source. 


\subsection{Alternative drying technology}

The volatile components targeted in drying are moisture and organic solvent (NMP) that are a part of the cathode or anode paste. The oven provides thermal energy to the feedstock continuously by convection, conduction or radiation in order to remove the targeted compounds from the battery components. In Iceland, geothermal power plants are typically operated with steam at 10-12 bar, but in some cases, a higher pressure up to 18 bar is applied. In this case we consider Reykjanes as a location due to the power plants proximity to a harbor and a developed industrial area, so

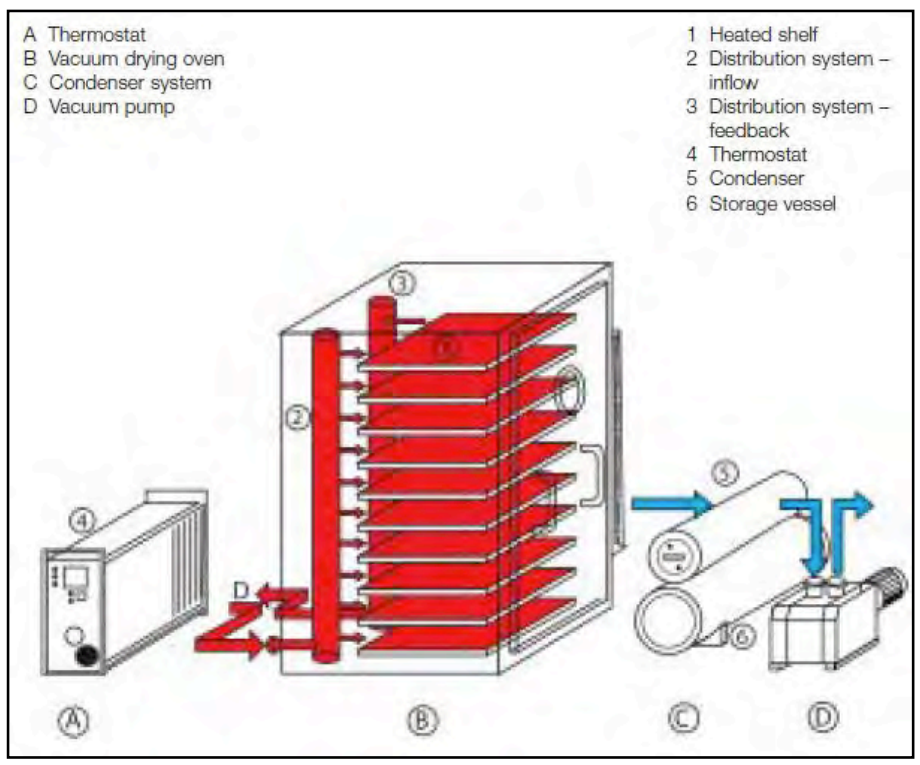

Figure 3-3 Schematic model of vacuum oven could use working fluid as thermal resource [9] geothermal steam at $18 \mathrm{bar} 207^{\circ} \mathrm{C}$ is used as a thermal resource for the analysis. However a resource at 9 bar and $173^{\circ} \mathrm{C}$, which would be more widely available, is quite sufficient for this process. As the factory is located close to the geothermal power plant, steam from two-phase separators could be applied directly. The power company, Hitaveita Sudurnesja, has offered $20 \mathrm{bar}$ steam to other customers at $4 \mathrm{USD} /$ ton and $6 \mathrm{bar}$ at $3 \mathrm{USD} /$ ton in 1995[10]. As a comparison a diatomite processing plant at Lake Myvatn that was in operation until 2004 paid $1 \mathrm{USD} /$ ton for geothermal steam. In this model, a steam price of $4 \mathrm{USD} /$ ton is assumed. In reality, this price highly depends on the negotiation with power companies. The optimal dryer technology for lithium ion battery production is a tray dryer (batch) using conduction heating method under vacuum conditions. Although the geothermal steam from well contains some deleterious materials, most of them would be contained within the liquid phase in the separators. Thus, we would be able to fill the geothermal steam into the entire cavity of shelves directly. As you can see in Fig 3-3, while the feedstock is placed on the shelves, the thermal energy is transferred to products by conduction. In addition to the conduction, it also could be combined with irradiative heating in order to accelerate the drying rate. We assume the new type of dryers will cost $20 \%$ more than normal electric dryers. As the cost of dryers is only $14 \%$ of production lines, it does not affect the overall cost of production significantly.

\section{Reduction in carbon emissions}

From the data shown in Table 3-2, we can see that the energy structure of each country has different features. Based on that data, the average emission from electricity generation for each energy profile is calculated. If we build a lithium iron phosphate battery production facility with $10 \mathrm{MW}$ power requirement in other countries, it will emit 36247 64771 tons of $\mathrm{CO}_{2}$ per year depending on the country's electric energy production profile. In Iceland, approximate $50 \%$ of energy consumption is still electricity, which emits $23.5 \mathrm{~g} / \mathrm{KWh} \mathrm{CO}_{2}$ on average [11]. The rest of the energy consumption will be replaced by geothermal steam, which emits $18 \mathrm{~g} / \mathrm{KWh} \mathrm{CO}_{2}$ in this case. Thus, the total $\mathrm{CO}_{2}$ emission in Iceland would be around 1818 tons of $\mathrm{CO}_{2}$ per year. In summary, this project in Iceland has 393.4-215.1 g/Ah lower $\mathrm{CO}_{2}$ emission advantage compare to other countries. However, we have to put it in mind that most of carbon dioxide is emitted naturally from geothermal area in Iceland. The 
emission from geothermal plants is already part of $\mathrm{CO}_{2}$ cycle, no new $\mathrm{CO}_{2}$ is being produced as is in the case of fossil fuel.

Table 4-1 Comparison of carbon emission for Li-ion factories with 10MW power requirement located in different countries [12].

\begin{tabular}{cccccc}
\hline $\begin{array}{c}\text { Various } \\
\text { Resource }\end{array}$ & $\begin{array}{c}\text { Average CO2 } \\
\text { emission (g/kwh) }\end{array}$ & China & USA & Germany & Japan \\
\hline Renewable & 50 & $0.4 \%$ & $2.8 \%$ & $11.6 \%$ & $2.7 \%$ \\
\hline Oil & 400 & $0.6 \%$ & $1.3 \%$ & $1.4 \%$ & $12.8 \%$ \\
\hline Gas & 430 & $0.9 \%$ & $20.9 \%$ & $13.7 \%$ & $26.1 \%$ \\
\hline Nuclear & 6 & $1.9 \%$ & $19.2 \%$ & $23.3 \%$ & $23.8 \%$ \\
\hline Hydro & 4 & $16.9 \%$ & $6.4 \%$ & $4.2 \%$ & $7.7 \%$ \\
\hline Coal & 925 & $79 \%$ & $49 \%$ & $45.6 \%$ & $26.6 \%$ \\
\hline Total & $100 \%$ & $100 \%$ & $100 \%$ & $100 \%$ \\
\hline $\begin{array}{c}\text { Average CO2 emission from } \\
\text { electricity (g/kwh) }\end{array}$ & 738.9 & 552.1 & 494.2 & 413.51 \\
\hline $\begin{array}{c}\text { Total emission from this project } \\
\text { per year (87.66 GWh) }\end{array}$ & 64771.9 & 48402.3 & 43321.5 & 36247.4 \\
\hline
\end{tabular}

\section{Profitability assessment}

We built a comprehensive model containing cost analysis, investment, operation, cash flow, profitability and sensitivity analysis in order to estimate the profitability of building a lithium iron phosphate battery factory using renewable energy in Iceland. We calculate NPV and IRR based on the current cost data on the market and some financial assumptions. The main results of this model are presented in the following text.

\subsubsection{Net present value}

Fig 5-1 shows that the NPV of total cash flow (for loan and equity) with $15 \%$ discount rate is $48.16 \mathrm{~m}$ illion USD after 15 years operation time. Also, NPV net cash flow (only for equity) with $15 \%$ discount rate is 52.57 million USD. The value of NPV of total cash flow and net cash flow take 9 and 8 years to turn positive, respectively. From the point of view of NPV, it seems a reasonably profitable business in Iceland. Building the factory at

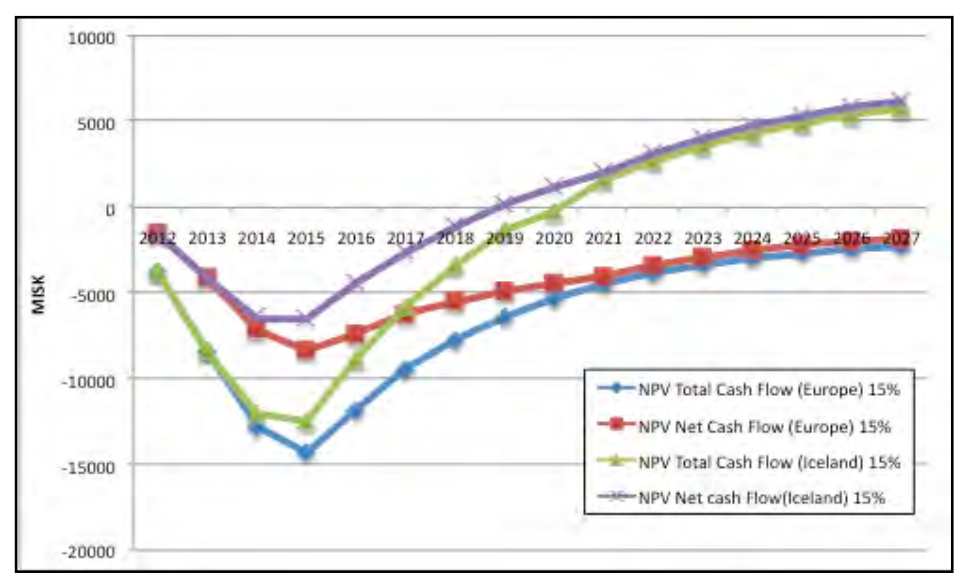

Figure 5-1 Accumulated NPV comparison between Iceland and other European countries. another location in Europe with similar operating environment, the accumulated net present value might turn negative due to much higher prices of industrial electricity. Applying European electric prices, the accumulated NPV of net cash flow will be -20.6 million USD, as shown in Fig 5-1. Other cost contribution might vary slightly depending on location but it is observed that energy price significantly affects net present value. The energy price will play more substantial part of the total variable as raw material prices are predicted to fall in the next 10 years. 


\subsubsection{Internal rate of return}

In terms of internal rate of return, it is used in capital budgeting to measure and compare the profitability of the investment. Fig 5-2 shows the internal return rate of total cash flow and net cash flow in Iceland is $22 \%$ and $27 \%$, respectively. On the other side, the internal return rate of total cash flow and net cash flow in Europe is $11 \%$ and $12 \%$, respectively. Although there is some risk and uncertainty in this

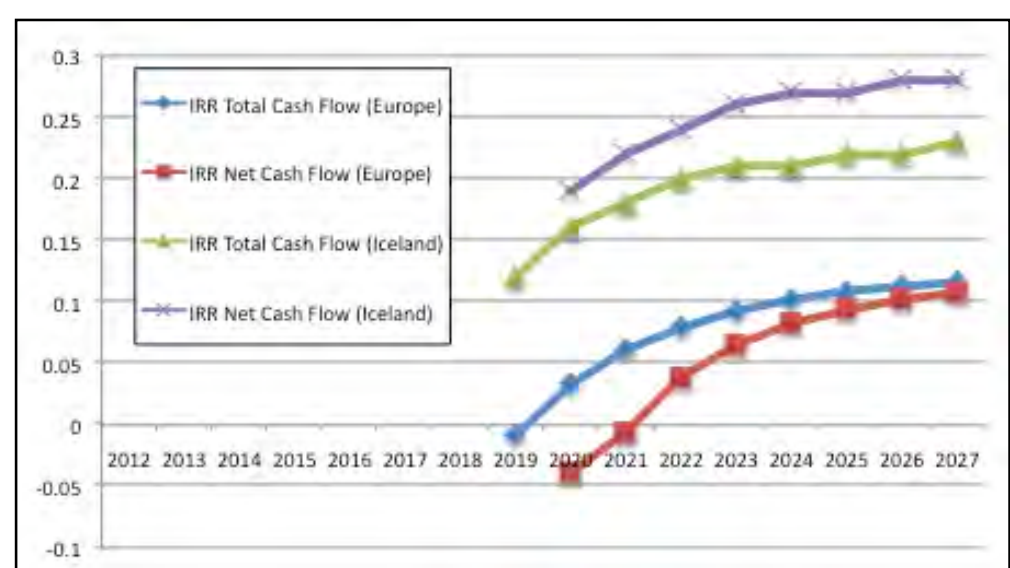

Figure 5-2 IRR comparison between Iceland and other European countries

project, IRR is higher than the cost of capital in the normal situation in Iceland. To compare to a common investment, it has a relatively high internal rate of return based on the assumption. However, 11 12\% of IRR is a normal and acceptable result for an investment project in other European countries.

\section{Conclusion}

With the anticipated reduction in material cost for Lithium-ion batteries, the energy cost for battery production will play a more important role in the overall cost of lithium ion batteries. According to our investigation, the energy consumption could range from 0.54 to 0.68 $\mathrm{KWh} / \mathrm{Ah}$ depending on the factory's design and production process. Although we did not get access to first-hand energy consumption data of each step from factories directly, we can infer that the main energy consumption steps in the procedure are drying room, vacuum dryers, and testing equipment from our production process analysis, and create a process model. In locations with access to geothermal heat, such as Iceland, it is possible to replace the electricity used as a heat source for the drying processes by geothermal steam, reducing energy cost in combination with reasonably priced electricity. According to the model, the energy consumption of removing the moisture content in $1 \mathrm{Ah}$ battery is $0.31 \mathrm{KWh}$, which is around half of the total energy consumption. The variable energy cost in Iceland could be reduced to $0.012 \mathrm{USD} / \mathrm{Ah}$ (0.007 USD for electricity; 0.005 for geothermal steam) if geothermal steam is used for drying. In this study Reykjanes in Iceland is considered as a location so geothermal steam at 18 bar $207^{\circ} \mathrm{C}$ is used as it is the available resource from an existing geothermal power plant. However a resource at 9 bar and $173^{\circ} \mathrm{C}$, which would be more widely available, is quite sufficient for this process. In this case, the ideal type of dryer and heating method for lithium batteries would be a tray dryer. A profitability model was built using current cost data based on operating environment in Iceland. According to this model, the accumulated NPV for equity with a $15 \%$ discount rate is 52.5 million USD and internal rate of return is $27 \%$. On the other hand, if we move the factory to other European countries with higher energy price $(0.18 € / \mathrm{KWh}[13])$ and the same cost assumption, the NPV for equity will fall down to -20.6 million USD. The internal rate of return will fall from $27 \%$ to $11 \%$. Moreover, with current feedstock prices the energy cost is estimated to be $1 \%$ with the Icelandic cost structure, while it would amount to $12 \sim 15 \%$ in other European countries based on average energy prices. The lower energy cost in Iceland results in an NPV less sensitive to fluctuation of energy prices. The geothermal resource seems to have a great economic advantage for lithium ion battery production due to lower energy prices, whether it is electric 
energy or direct use of geothermal heat. Another feature of even more importance is that the lower carbon footprint of geothermal heat and renewable electricity, will result in 3442962953tons lower $\mathrm{CO}_{2}$ emissions per year from running a battery factory with $10 \mathrm{MW}$ power consumption and 160MAh production capacity, compared to the emissions where at he electric production profile is more traditional as would be the case in Europe or China. That means that only $2-5 \%$ percent of the carbon dioxide would be emitted as a result from this process as compared to traditional energy usage. This could bring some practical carbon emission credit value or an advantageous position on g reen marketing. Although most of battery companies still focus on reducing the cost of raw material at this moment, the energy cost will become more and more critical in the entire cost structure with future price reductions of raw material. The trend for companies planning to develop production in Europe will be a higher emphasis on selecting a location with reasonably priced renewable sources for heat and electric energy. The access to low cost low emission energy sources should be a significant factor when selecting a location for Lithium ion battery production.

\section{References}

[1] Pike Research, "Asian Manufacturers Will Lead the \$8 B illion Market for Electric Vehicle Batteries", Retrieved 10.01.2010, from Pike Research: http: //www.pikeresearch.com/ newsroom/asian-manufacturers-will-lead-the-8-billion-marketfor-electric-vehicle-batteries

[2] Zackrisson M \& Orlenius J, Life cycle assessment of lithium-ion batteries for plug-in hybrid electric vehicles e Critical issues. Journal of Cleaner Production, 2010, pp.15171527.

[3] Nuutinen, M, Lithium-ion battery factory relocation from China to Finland. Material science and engineering. Helsinki: Helsinki university of technology, 2007, pp.68-69.

[4] She Haung $\mathrm{Wu}$ and Yang-Ting Lai, The effects of the moisture content of LiFePO4/C cathode and the addition of $\mathrm{VC}$ on the capacity fading of the LiFePO4/MCMB cell at elevated temperatures. The electrochemical Society, 2007.

[5] Dr. Michael Eastman, Smart Sensors Based on Piezoelectric PVDF, 2010, pp-6

[6] LICO Technology Corporation, LHB-108P Hydrophilic Binder, 2008, pp-6

[7] Taminco Co, N-Methylpyrrolidone Electronic grade Technical Data Sheet, 2004, pp-1

[8] Mujumdar A. S, Handbook of Industrial Drying. Taylor \& Francis Group LLC, 2006, pp.1108-1109.

[9] Weiss Gallenkamp, Vacuum oven and drying oven VVT, 2010, pp-4.

[10] Invest in Iceland Agency, Doing business in Iceland 8 E dition. Reykjavik: Iceland investment agency, 2010.

[11]Landssvirkjun, Landssvirkjun's carbon footprint, Reykjavik: Landssvirkjun, 2009, pp-11.

[12] World Energy Council, World Energy council. Retrieved 10 1, 2010, from World Energy council:http://www.worldenergy.org/publications/survey_of_energy_resources_2007/geo thermal_energy/737.asp

[13]Europe's Energy Portal, Industrial Electricity Rate, November 2009, http://www.energy.eu/\#Industrial 